\title{
ANNUAL MEETING OF THE MONTREAL BRANCH.
}

The seventh annual general meeting of the Montreal Branch of the Entomological Society of Ontario was held on Monday, the 17 th May, I880, at the residence of the Vice-President, Mr. H. H. Lyman.

An interesting paper was read by Mr. Couper on the Milk-weed (Asclepias tuberosa) and some of its insect frequenters. The paper drew attention to the curious fact that the colors of the different insects feeding upon this plant were, almost without exception, red and black.

The Secretary and Treasurer read his annual report, which showed the finances to be in a most satisfactory condition.

The election of officers then took place, resulting as follows:

President-G. J. Bowles.

Vice-President-G. B. Pearson.

Secretary and Treasurer-Geo. H. Bowles

Curator-F. B. Caulfield.

Council-Messrs. H. H. Lyman, Wm. Couper and Robert Jack.

A short time was pleasantly spent in examining several cases of rare Lepidoptera belonging to Mr. Lyman, after which the meeting adjourned.

Geo. H. Bowles, Secretary and Treasurer.

\section{DEAR SIR, -}

\section{CORRESPONDENCE}

Mr. W. H. Edwards' note of Oct. 20 recalls a very remarkable gathering of Danais archppus which came under my own observation, at Racine, Wisconsin, in the first week of Sept., 1868 . The insect appeared in great numbers, and gathered in several swarms about trees in the vicinity. The day was cloudy, but without rain. Shortly after noon the swarms seemed to gather and settled upon a tree in my garden, a wellformed black oak about $\mathrm{I} 5$ inches in diameter at the trunk, and perhaps 40 feet high. The swarm covered the southern aspect of this tree so 
abundantly that the green of the leaves was quite obscured by the brown of the wings of the butterflies. A few sailed back and forth through the air as if seeking a place to alight, when the wings of those sitting, opening and shutting as if by a single impulse, caused the prevailing color to shift from the dark hue of the upper surface to the lighter color of the lower surface. They remained until after nightfall, but were gone when we looked for them in the morning. No attempt was made to capture or count them, but the swarm must have contained some thousands.

S. H. Pearody, Champaign, Ills.

DEAR SIR,-

Our season here is remarkably early ; the following insects have been observed on dates named :

Camberwell Beauty, $V$. antiopa............March I 8

Smail Blue Butterfly, Lycaena neglecta......... “

Cabbage Butterfly, Pieris rapa, emerged from chrysalis in the house. ........................ 30

Sulphur Butterfly, C. philodice............... April 4

Cabbage Butterfly, $P$. rapre...............

Green Emperor Moth, A. luna, just out..... ...April I4

Ajax Swallow-tail, $P$. ajax ... ......... April $\mathbf{6} 6$

American Silk-worm, S. cecropia, just out.........April s 8

Currant Saw-fly, N. ventricosus............ "

Grape-vine Flea Beetle, Haltica chalybea....... "

The Colorado Potato Beetle, Doryphora decemlineata.Apr. I I

E. W. Claypole, Yellow Springs, Ohio.

\section{DEAR SIR,-}

On Friday evening last $\left(25^{\text {th }}\right)$ while sitting reading, I heard a noise in my breeding box, and on taking it down I saw a fine specimen of $P$. cresphontes, which had been out for some time, as it was full of life. I was afraid that it might be hurt by flitting about, but it was perfectly safe. I am not sure when it went into the chrysalis, but it was late in October. I got the larva on the Irth Oct., and it fed a good while. It is not large, measuring just $3 / 2$ inches when set out. My room has not been very warm, and nothing else has yet come out.

Hamilton, Ont., Jan'y 26, r880. William Murray. 